\title{
Diminazene for COVID-19: a missed opportunity?
}

\author{
Raquel Barrantes Gallego ${ }^{1}$ and Francisco F R Vidigal ${ }^{2}$ \\ ${ }^{1}$ Complejo Hospitalario Llerena-Zafra \\ ${ }^{2}$ Complejo Hospitalario Universitario de Badajoz
}

October 31,2020

\begin{abstract}
Angiotensin Converting Enzyme 2 (ACE2) is the receptor the new coronavirus SARS-CoV-2 binds to for cell entry. ACE2 is also an important player in the Renin Angiotensin System (RAS). ACE2 and RAS appears to be central in coronavirus disease (Covid-19) pathophysiology. Covid-19 might be regarded as a virus-induced "RAS disorder". Drugs acting upon RAS components may offer potential therapeutic value in Covid-19. The authors advocate diminazene aceturate (DIZE), a putative ACE2 activator, as a feasible treatment option unduly disregarded a priori, likely due to lack of licensing for human use. However, DIZE has been extensively employed in African trypanosomiasis patients with little toxicity reported. With the current pandemic causing health issues on a large scale worldwide, the properties of DIZE remain to be investigated in Covid-19. A drug that is available, inexpensive and with a long track record of safe usage should be considered, particularly while effective alternatives remain scarce.
\end{abstract}

\section{Hosted file}

Review DIZE BJP.pdf available at https://authorea.com/users/371898/articles/490080diminazene-for-covid-19-a-missed-opportunity 


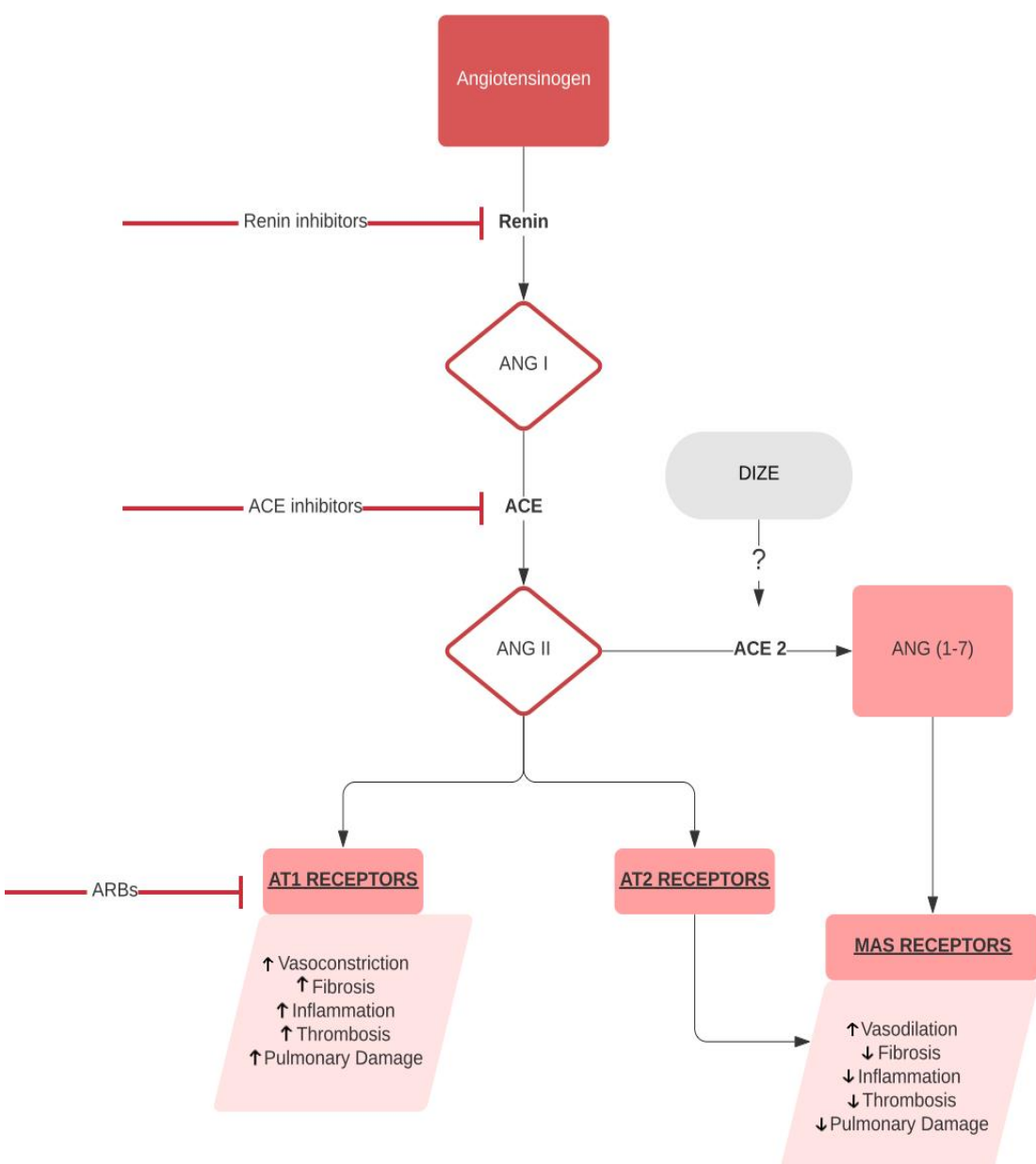



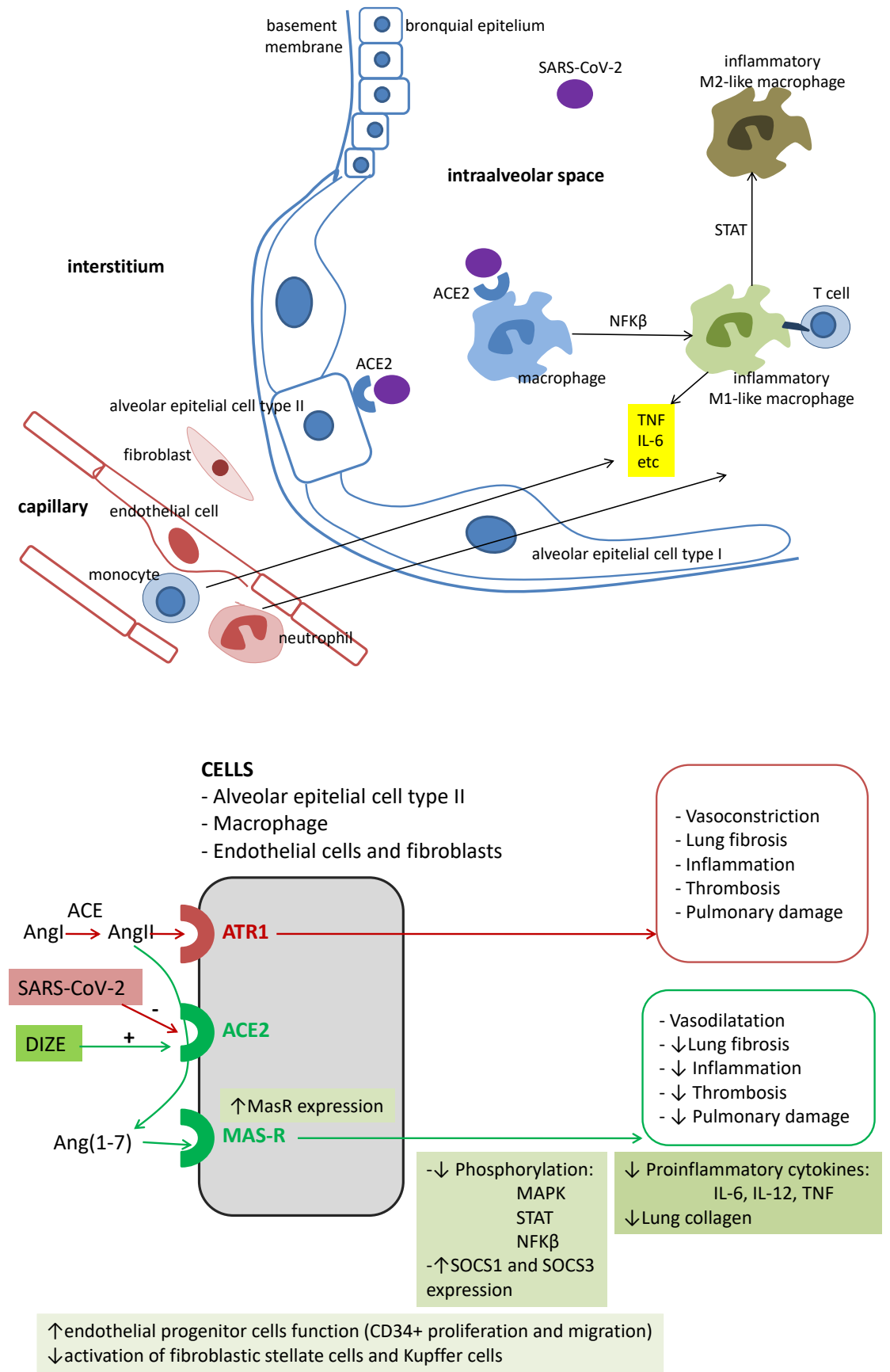

\section{Hosted file}

Article DIZE Table 2.pdf available at https://authorea.com/users/371898/articles/490080diminazene-for-covid-19-a-missed-opportunity

\section{Hosted file}

Article DIZE Table 1.pdf available at https://authorea.com/users/371898/articles/490080diminazene-for-covid-19-a-missed-opportunity 